\title{
Ethical Issues in Research Processes: Informed Consent, the Role of the Researcher, Access to Research Sites and Research Subjects
}

\author{
Lina Zhang \\ Teachers' College Shenyang University \\ Shenyang, China
}

\author{
Zhiqing Liu \\ Beijing Normal University \\ Beijing, China
}

\begin{abstract}
Ethical dimensions, which character is a social life in all parts of the society exist in every social research. The simple reason for that is that research concerns getting data from people, and about people. Varieties of problems probed by social researchers and the methods utilized by them are inevitably a source of ethical issues. In theory at least, this means that each stage in the research sequence may be a potential source of ethical problems. (Cohen et al 2000. P. 49). However, a thorough research proposal will have anticipated the ethical issues involved, and will show how they will be dealt with (Punch. 1998). This paper here will examine the main ethical issues researchers face in the course of their social science research with reference to the research project of Constructing the Ethos of Tolerance and Respect in an Integrated School: the Role of Teachers written by Caitlin Donnelly.
\end{abstract}

Keywords-ethical issues; educational research process

\section{INTRODUCTION}

The paper has four parts. Firstly, outline introduction to the research and all stages of the research process in which researchers conduct social investigations. Secondly, examine ethical issues and the research methods in general that social researchers use in the research activities. Thirdly, explore the types of issues that the researcher faces in the particular project occurring in the different stages as well as involving a series of methods used by the social researcher. Finally, come to the conclusion.

\section{EDUCATIONAL RESEARCH AND THE RESEARCH PROCESSES}

\section{A. What is Research and Educational Research?}

What is the exact definition about the word research? According to the literature, some statements may give an answer to the question. The Oxford Encyclopedic English Dictionary defines it as:

- the systematic investigation into the study of materials, sources etc. in order to establish facts and reach conclusions
- An endeavor to discover new or collate old facts etc. by the scientific study of a subject or by a course of critical investigation.

It suggested that research is a systematic effort to provide answers to Questions. In 1978, the author Mouly defined research as:

Research is best conceived as the Process of arriving dependable solutions to problems through the planned and systematic collection, a11alysis, an Interpretation of data. It is the most important tool for advancing knowledge, for promoting progress, and for enabling man to relate more effectively to his environment, to accomplish his purposes and to resolve his conflicts. (Mouly, 1978, cited in Cohen and Manion, 1994, p.40)

However, what is educational research? Educational research is quite different from other social research in that it is completely concerned with people, including researchers, participants and consumers. And Stenhouse (1984. cited in Wellington, J. 2000. P.11) defined it as systematic activity that is directed towards providing knowledge or adding to the understanding of existing knowledge that is relevance for improving the effectiveness of education.

This definition depends on providing knowledge and understanding existing knowledge to improve educational effectiveness.

\section{B. What is the Research Process?}

Much of the literature on social and educational research is concerned with the technical procedures, such as design, collection and analysis of research data, etc.

John Dewey(1933,p.12) has provided an outline of the research process in six steps, which starts with a felt need, the problem, the hypothesis, collection of data as evidence, concluding belief and general value of the conclusion. Another voice from Howard and Sharp (1 983,cited in Wellington J. 1998. P.46) about the research process is the 'ideal' research sequence based on seven-steps. It begins with: identify broad area, select topic, decide approach, formulate plan, collect information, analyze data and present findings. This 'ideal' model of research means it does not work like that in reality. (Medawar, 1963.cited in ibid). 
However, Jerry Wellington (2000. PP.47-48) has proposed

a cyclic research process, which is as in "Fig. 1":

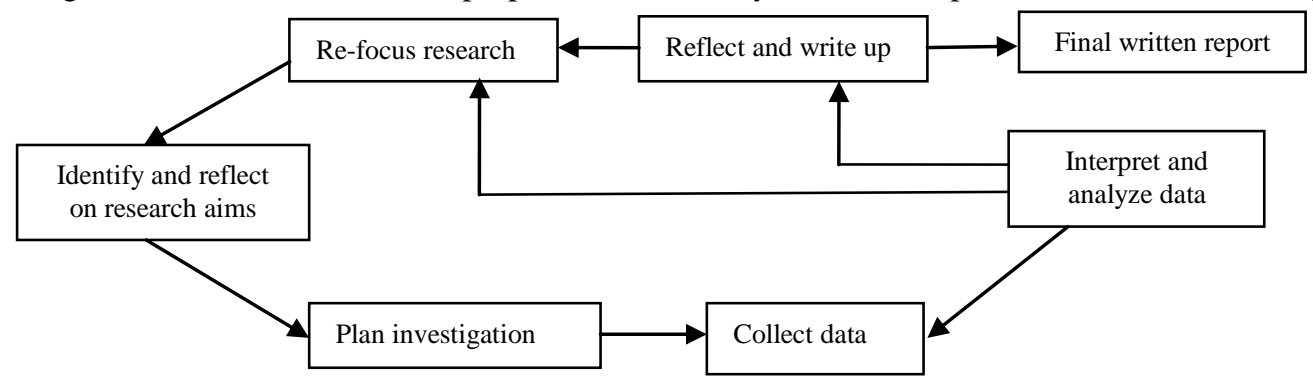

Fig. 1. The cyclic research process.

In this cycle process, researchers can re-focus their research, from research aims and investigation plan to collection of data when they realize something is wrong with the targets and/or methods of the research, and so on. This is a more realistic approach.

\section{Ethical Issues and Research Methods}

Ethical issues are a common feature in the history of both scientific and educational research (Wellington J. 2000. P. 2). There are two main kinds of ethical issues in social research according to the substantial literatures. One literature is the code of ethical and professional conduct for research, providing researchers with checklists of points to consider. The other one is the various commentaries in ethical issues, describing which issues happen for different researchers in different research project. Miles and Huberman (1994:290-7) list and discuss 13 ethical issues: worthiness of the project, competence boundaries, informed consent: benefits, cost and reciprocity, harm and risk, honest and trust, privacy, confidentiality and quality, ownership of data and conclusions, and the use and misuse of results.

Ethical issues can arise from several aspects of the research process. Research methods that are used to obtain answers are the main source of constraining and influencing the process of the research and also resulting in ethical dimensions in doing research. That means the ethical issues usually originate from the complexities of research methods in social research, such as in the survey methods, interviews and observations methods, action research, and ethnographic studies. It is undoubted that methodological and ethical issues are inextricably interwoven in much of the research we have designated as qualitative or interpretive (Cohen et al.2000. P.66). As Hitchcock and Hughes note:

Doing participant observation or interviewing one's peers raises ethical problems that are directly related to the nature of the research technique employed. The degree of openness or closure of the nature of the research and its aims is one that directly faces the teacher researcher. (Hitchcock and Hughes, 1989:199 cited in Cohen et a1. 2000. P.66)

This quotation showed that educational research like other social researches might also be unethical in its methods. However not only researchers are responsible for contribution to knowledge, but also they have an equally binding responsibility to protect the benefits of the participants. Sometimes ethically questionable practices can be avoided or minimized by the use of alternative research procedures. However, they often cannot, and in this case, social scientists face a conflict between two values. (Kidder and Judd, 1986.P.510)

\section{ETHICAL ISSUES ARISING FROM QUALITATIVE RESEARCH IN A MIXED SCHOOL OF NORTH IRELAND}

\section{A. The Research Project}

The article here-Constructing The Ethos of Tolerance and Respect in an Integrated School: The Role of Teachers, which was written by Caitin Domelly in 2002, was an interview and observation research project attempting to explore how teachers develop tolerance and respect within an inclusive school in Northern Ireland. It concerned the influence of teachers' own personal value and assumptions on the school ethos in a religiously integrated school. It also concerned the different beliefs in Catholic and Protestant within the mixed school. A variety of research methods were used, including interviews with teachers and the head, and the periods of observation were carried out. Data was gathered by the qualitative methods. This part of the paper will concentrate on the ethical issues raised by working in this way in the integrated school.

\section{B. Interviews, Observations and Informed Consent}

Informed consent is the foundation of ethical procedure. It has been defined by Diener and Crandall as 'the procedure in which individuals choose whether to participate in an investigation after being informed of facts that would be likely to influence their decisions' (Diener and Crandall,1978.cited in Cohen, L. et al. 2000. PP.50-51). The principle of informed consent arises from the subject's right to freedom and self-determination. That is to say, informed consent implies informed refusal. Baumrind (1972. cited in Bower, T. R. and Gasparis P. 1978. PP. 36-43) holds informed consent to be the most important of ethical dicta and also the one most commonly violated--she expresses outrage at acts, which rob others of their freedom of choice. Wolfensberg (1967. ibid) is another who sees informed consent as a key issue. Interviews and observations as research methods have their ethical issues. The main area of ethical problems here related to them is informed consent. For example, who should give the informed consent, and for whom and what? How might the research help or harm the interviewees? The covert research, which appears to violate 
the principle of informed consent, invades the privacy of subjects and private space, treats the participants instrumentally as research objects-and places the researcher in a position of misrepresenting his/her role. (Mitchell, 1993. cited in Cohen, L. et a1. 2000. P.314)

This project researcher implemented some of the intervention strategies in the integrated schoo1. The nature and aims of the project were explained to the teachers and the head prior to the interviews and observations. However, it is not completely understood as to what 'informed consent' involves I. e. how much information should be given in advance of the studies? I doubted that it was obtained and adhere the reasons for this.

What the sensitive nature of the project is to show teachers' own personal values and assumptions of the mixed religion school--Catholic and Protestant. Yet some teachers are Catholics and others are Protestants. Being a member of either religious group in the school entails one being privy to a set of values, assumptions and traditions not associated with the other group(Murray, 1985. cited in Donnelly, C. 2003. P.268). So it is likely to produce uncomfortable feelings because of their own biases and views in different religions. At the same time they tend to create a harmonious atmosphere in the mixed school. Therefore, the researcher made a decision to hide the aim of the wider, the more personal information during the interviews and observations of teachers in the school staff room and to focus on general factors of the project. It is certain that the research did not obtain the fully informed consent. Truly 'informed consent' was not emphasized as much as necessary. The researcher did not aim to conceal the wider intent of the project, but researcher did not explain it in a great length before the interviews and observations.

\section{Interview, Observation and the Ethics of Access}

At this stage of access to people, to places or to organizations, appropriateness of topic, design methods, guarantees of confidentiality, analysis and dissemination of findings must be negotiated with relative openness, sensitivity, honesty, accuracy and scientific impartiality (Cohen, L.et a1. 2000. P.53). Whatever plans we might make in educational research. they are almost certain to be compromised documents - or in some cases completely scuppered--by the problem of gaining access to what we want (Wellington J. 2000. P.63).

In this research project, the researcher also encountered the ethical issues of access related to openness, sensitivity and honesty during the process, of access to research sites and people. The researcher carried out the research at the Northern Ireland integrated school where a particularly useful forum for such research is provided. The researcher wanted to look at the role which the teachers' personal values and assumptions play in the integrated school where there are often forceful opposition along religion - ethic lines. This raised a difficult question about how honest and overt the researcher should be about the aim of the research. It is obvious that if too much attention as paid to the teachers' owns religious beliefs and the understanding of other's values, the researcher would not be welcomed to the school, teachers would object to the whole research, and would deny the researcher access to their staff rooms. Therefore the researcher explained the research project in terms of how teachers construct the ethos of tolerance and respect within a mixed school, but she/he did not fully explain the aim of the research to the teachers. The teachers' own religious beliefs and the value of others' beliefs were mentioned during the process of the interviews and observation. Thus, the research did not follow precise ethical guidelines, which is the usual practice.

\section{Methodological Issues: The role of the Researcher}

In social and educational research the researcher is always the key 'instrument'. His or her background and experience, such as age, gender, ethnicity, social class, sexual orientation, and religion etc. all play a key role and affect the researched. In addition, building trust and developing relationships with respondents is very crucial simply because a rapport in the research can significantly foster the research, and is a source of support. On the contrary, a non-rapport may produce despair, embarrassment and despondency. Researchers who attempt to become accepted by a group, but who do not deceive them totally have adopted less extreme and less deceptive strategies in order to gain acceptance and establish a rapport (Wellington. 2000. P.42).

In this research project there are also some ethical difficulties related to the researcher's background---religion. The qualitative research with interview and observation methods in this project, asks the researcher to screen their own effect on the situation they are researching, as a strategy for illumination and validation of data. Relationship with the teachers is the area that needs especially careful monitoring. However, one of the crucial questions that teachers had to be sure of before they could develop relationships was whose side the researcher was on. Therefore on entering the case study, it is not likely for the researcher to be detached and objective; the exchange between the researcher and the teachers is often neither natural nor neutral because of his/her Catholic and researcher identities. In the interview of the head and deputy head, the researcher was considered as an 'aloof outsider' due to the researcher identity in the schoo1. So, the unified and peaceful school without any problems of cultural and religious tensions was presented before the researched. In addition, because of the Catholic identity, it is much easier for the researcher to establish a rapport with the Catholic teachers than the Protestant ones. Therefore, during the interviews and observations, the Catholic teachers actively open responded to the 'sensitive' issues compared to the Protestants 'obviously because they considered the researcher to be one of them'(Murray, 1985. cited in Donnelly, C. 2003. P.268). The conversations and behaviors of the Protestants were always far away from the issues that are likely to produce uncomfortable feelings, obviously because they considered the researcher to be an outsider. It is clear that the situation of different relationships with Catholics and Protestants made the research inside the mixed school quite difficult. 


\section{CONCLUSION}

Ethical issues of the research arising from different aspects of this research project shows that the main moral dilemma the researcher faced concerned the balancing of the values of the researcher's obtaining knowledge in an unethical way, against the need to inform the negotiations, which take place between the researcher and researcher participants. Ethical problems begin with the choice of research methods, the use of interviews and observations in qualitative research. When the research started, the ethical issues of gaining the informed consent of teachers, access to research sites and people, openness and honesty in the relations between the researcher and the researched are constantly encountered. The problem of how much to tell people about the research is hard to be resolved by researchers, because the precise focus often does not become clear until the project is well underway. Moreover, the researcher who undertakes qualitative research also has particular problems, as to which access to the field may well depend on partial concealment of the purpose of the research. Apart from this there are ethical problems in dealing with developing relationships with respondents because of the role of the researchers, concerning the researcher identity and religious identity. All these problems, which are an inevitable part of social research, are not unique to interview and observation research, but they emerge in this project.

The fact is that it is not possible to identify all potential ethical questions or adjudicate on what is correct researcher behavior (Cohen, 2000. P.71), because it is always relatively easy to prescribe a set of abstract principles, while it is less easy to apply them to enforce them. (Burgess, R, 1989. P.74 cited in Wellington, J. 2000. p. 66). However, Maykut and Morehouse (1994, P.70. cited in Wellington, J. 2000. P.66) are in favour that 'deceptive and covert practices are not in keeping with ethical practice'. Instead, Scott and Usher (1999, PP.129-3 0. ibid) take the view that deception is a price worth paying for minimizing the disturbance for a natural setting and thereby increasing 'validity'. Although not all the problems can be resolved by the code of ethics, researchers should fully consider the balance between the principles of ethics and awareness of practice. Discipline without awareness may result in largely mechanical behavior: whereas awareness without discipline can produce inappropriate responses (Cohen, L.2000. P.72).

\section{REFERENCES}

[1] Bower, T. R. and Gasparis, de P. 1978. Ethics In Social Research. Praeger Publishers Praeger Special Studies

[2] Burgess G R. (Ed.)1985. Issues in Educational Research Qualities Methods. The Falmer Press

[3] Beckerl S. and Alan, B. (Ed. )2004. Understanding Research For Social Policy And Practice. SPA

[4] Cohen L. and Manion L. 1994. Research Methods in Education. (4th Ed.) Routledge London.

[5] Cohen,L. ,Manion,L. and Morrison,K. 2000. Research Methods in Education. (5th Ed. ) Routledge Falmer London and New York

[6] Donnelly, C. 2002. Constructing the ethos of tolerance and respect in an integrated school:the role of teachers. British Educational Research Journal V01.30, No. 2. April 2004
[7] Dewey, J. 1933. How we think:a restatement of relation of reflective thinking to the educative process. Boston,Muss.

[8] Halpin, D. and Troyna,B. (Ed.)1994. Researching Education Policy: Ethical and Methodological Issues. The Falmer Press London. Washington, D. C.

[9] Kidder' H. L. and Judd, M.,C.1986. Research Methods In Social Elations. CBS College Publishing

[10] Laine de M. 2000. Fieldwork, Participation and Practice ethics and Dilemmas in Qualitative Research. Sage Publications London. Thousand Oaks. New Delhi

[11] Miles, B. M. and Huberman, A. M. (2nd) 1994. Qualitative data analysis. Thousand Oaks; London; New Delhi

[12] May, T. 2001. Social Research Issues, methods and process. Open University Press Buckingham. Philadelphia

[13] Mauthner, M. ,Birch, M. ,Jessop, J. and Miller, T. (Ed3 2002. Ethics in qualitative research. India at Gopsons Papers Ltd, Noida

[14] OECD.1995. Educational Research and Development Trends, Issues and Challenges. Head of Publications Service, OECD

[15] Punch, E K. 1998. Introduction to Social Research Quantitative \& Qualitative Approaches. Sage Publications London. Thousand Oaks. New Delhi

[16] Shipman, M. 1988. The Limitations of Social Research London and New York

[17] Sales, D. B.and Folkman, S. (Ed.) 2001. Ethics In Research With Human Participants. American Psychological Association Washington, DC

[18] Walford, G(Ed.)1991. Doing Educational Research. Routledge London and New York

[19] Walliman, N. and Baiche, B. 2001. Your Research Project a step-bystep guide for the first-time researcher. Sage Publications London. Thousand Oaks. New Delhi

[20] Wellington, J. 2000. Educational Research Contemporary Issues and Practical Approaches. Continuum London. New York. 